\title{
An evaluation of the economic viability of environmental offsets in the saltworks industry
}

\author{
Rogério Taygra Vasconcelos Fernandes ${ }^{1 * \text { [D }}$ \\ Aruza Rayana Morais Pinto ${ }^{3}$ (i) \\ Raimunda Thyciana Vasconcelos Fernandes ${ }^{3}$ (iD Jônnata Fernandes de Oliveira $^{4}$ (iD \\ José Luís Costa Novaes ${ }^{\text {iD }}$
}

\begin{abstract}
${ }^{1}$ Centro de Ciências Agrárias, Universidade Federal Rural do Semi-Árido (UFERSA), 59625.900, Mossoró, RN, Brasil. E-mail: rogerio.taygra@ufersa.edu.br. "Corresponding author.

${ }^{2}$ Instituto Federal do Maranhão (IFMA), Campus Avançado Carolina, 65980.000, Carolina, MA, Brasil.

${ }^{3}$ Equilíbrio Gerenciamento Ambiental, Mossoró, RN, Brasil.

${ }^{4}$ Instituto Federal do Maranhão, São Luís, MA, Brasil.

ABSTRACT: The extraction of sea salt depends on the occupation of large areas at the estuary banks, many of them inserted in Permanent Preservation Areas (PPAs). Thus, the objective was to evaluate the economic viability of Environmental Offsets (EO) as an alternative to the unoccupied PPAs in the saltworks. In order to do so, 27 solar saltworks installed in the region of the Brazilian White Coast were evaluated for the occupation of PPAs - measured using images from satellite, georeferenced, vectored with corresponding PPA bands generated - and estimated to EO (Impact Degree $x$ Sum of the investments necessary to implement the project) and Economic Impact (Net Present Value, with long-term interest rate of 7\%) of vacating PPAs. It was considered that EO was feasible whenever the costs resulting from it were lower than the economic impact caused by the vacancy of the PPAs. The PPAs were tthe productive area of the saltworksthat occupied $13.70 \%$ of PPAs. For all the evaluated enterprises the value corresponding to EO was lower than the Economic Impact resulting from the vacancy of the PPAs. Thus, EO is an economically viable and more attractive alternative to the eviction of PPAs by the saltworks industry and may also provide environmental gains due to the financing of conservation units in the areas of influence of the enterprises. However, there is a need to improve the methodology used to estimate the EO, since a maximum limit is set, the environmental impacts caused by the projects are underestimated. Key words: economic impact, environmental impacts, ecosystem services, mangroves, permanent preservation areas.
\end{abstract}

Uma avaliação da viabilidade econômica de compensações ambientais na indústria salineira

RESUMO: A extração de sal marinho depende da ocupação de grandes áreas às margens de estuários, muitas delas inseridas em Áreas de Preservação Permanente (APPs). Assim, objetivou-se avaliar a viabilidade econômica da Compensação Ambiental (CA) como alternativa à desocupação de APP pelas salinas. Para tanto, 27 salinas instaladas na região da Costa Branca brasileira foram avaliadas quanto à ocupação de APPS - mensuradas por meio de imagens de satélites, georreferenciadas, vetorizadas com a geração de bandas de APP - e estimados a CA (Grau de Impacto x Somatório dos investimentos necessários para implantação do empreendimento) e o Impacto Econômico (Valor Presente Líquido, com taxa de juros de longo prazo de 7\%) da desocupação das APPs. A CA foi considerada viável quando seus custos resultantes foram menor do que o impacto econômico causado pela desocupação das APPs. A área produtiva média das salinas ocupa 13,70\% de APP. Para todos os empreendimentos avaliados, o valor correspondente a CA foi menor que o Impacto Econômico resultante da desocupação das APP. Assim, a CA é uma alternativa economicamente viável e mais atrativa frente à desocupação das APP pela indústria salineira, podendo ainda propiciar ganhos ambientais em decorrência do financiamento de Unidades de Conservação nas áreas de influência dos empreendimentos. Evidencia-se, contudo, a necessidade do aprimoramento da metodologia usada para estimar a CA, já que fixado um limite máximo, os impactos ambientais provocados pelos empreendimentos são subestimados.

Palavras-chave: áreas de preservação permanente, impactos econômicos, impactos ambientais, manguezais, serviços ecossistêmicos.

\section{INTRODUCTION}

The extraction of sea salt is an activity developed over 500 years in the north coast of Brazil (TRINDADE \& ALBUQUERQUE, 2005; VITA et al., 2007; COSTA et al., 2013; DINIZ et al., 2015), which makes it an important productive sector, responsible for the generation of more than 70 thousand direct and indirect jobs (SIESAL, 2016). Despite the economic and social importance, salt extraction depends on the occupation of large areas on the banks of estuaries and bays of arid and semi-arid regions (DAVIS, 2000; 
ROCHA et al., 2012), resulting in the degradation of coastal ecosystems such as mangroves and Apicuns (BARBOSA, 2001; GT-SAL, 2017). These ecosystems are recognized for their high biological productivity, for performing ecosystem services of great economic importance and important areas for the maintenance of marine and freshwater aquatic diversity (LEE et al., 2014; NAGELKERKEN et al., 2014; SCHAEFFER-NOVELLI et al., 2012). Due to the importance of these areas for the preservation of natural resources and maintenance of biodiversity, the Brazilian government, through Federal Law $\mathrm{N}^{\circ} 12.651 / 12$ (New Forest Code), granted to these environments the status of Permanent Preservation Areas (PPA), ensuring to these, as a rule, integral protection, establishing their immediate evacuation and recovery in cases of degrading activities or actions (BRASIL, 2012). However, the same law gave the possibility of developing activities classified as being of public utility, among them mining, a group in which the extraction of sea salt is inserted (SANTOS \& LEITE, 2011). The dubious aspect of the legislation, which now regulates the protection of mangroves, sometimes allows the installation of public activities in these ecosystems, which results in a scenario of conflict and legal uncertainty, since depending on the interpretation, both those who advocate the eviction and preservation of the PPAs, as well as those who defend the permanence of the occupation and the development of the saltworks activity are supported by the current legislation.

One option to minimize conflict is sustainability. In this way, according to the 2030 Agenda, conceived by the United Nations Organization, among its 17 sustainable development goals, it is expected to progressively improve, by 2030 , the efficiency of global resources in consumption and production, and to commit to decouple economic growth from environmental degradation. Similarly, from Paris climate agreement, countries such as Brazil agreed in 2015 to reduce greenhouse gas emissions by 2025 , including by reforesting degraded areas. As a contribution to the objectives of the agreement, countries have submitted comprehensive national climate action plans (NDCs). Thus, these are not yet enough to reach the agreed temperature objectives, but the agreement traces the way to further action.

From this perspective, a sustainable measure is to adopt the so-called "Environmental Offsets" (EO), an economic instrument of remuneration based on the precepts of ecological valuation, and which seeks to translate in economic terms the values associated with sustaining life, goods and services provided natural ecosystems (BORN \& TALOCCHI, 2002, CAMPHORA \& MAY, 2006). The EO has been used successfully in several countries of the European Union and the United States of America, where it is used as a complement to measurerevention and mitigate environmental impacts (IUCN, 2004).

In Brazil, the EO instrument was created through Law 9.985/2000, which established the National System of Nature Conservation Units (NSCU), regulated by Decree no. 6.848/2009, can be understood as a way to compensate for environmental damages considered inevitable and irreversible, acting as an equivalent substitution of an environmental patrimony that will be lost, altered or de-characterized (SÁNCHEZ, 2008). In practice, when a enterprise has the potential to generate environmental damage that can not be avoided, it is converted into a financial value by way of offsets, which will be allocated to the Caixa Econômica Federal Environmental Compensation Fund, possible from Law 13.668/2018), created to receive the EO resources and intended to Conservation Units (BECHARA, 2009).

In this context, COELHO \& LINHARES (2006) studying environmental offsets to the urban arborization of Vitória - ES, Brazil, for cases where the construction and/or reform of property, imply in removal or relocation of trees in vegetative and health good conditions, calculate this EO on the basis of the costs of producing seedlings, planting, annual pruning, annual phytosanitary treatment and removal, plus a rate of up to $50 \%$ of the total value, which takes into account the environmental value of each specimen according to its nature. Thus, according to these authors, the EO was applied in 12 cases, in which the tree remotion was inevitable, resulting in 25 tree remotions and demonstrated to be an efficient tool for the management of urban trees, pointing out the importance of including the tree component in the implementation of new construction projects in the city.

In view of exposed; although, it is likely that the recovery of PPAs currently occupied by the saltworks industry will promote significant environmental benefits in the form of ecological services (BARBIER, 2007), it is feared that the aforementioned benefits will not suffice in the face of the costs resulting from the loss of productive area of the salt flats, which could even lead some companies to bankruptcy, with social repercussions such as income reduction and unemployment of the local population.

Given the uncertainties, risks involved, seeking to reconcile the maintenance of ecological services produced by coastal ecosystems and the economic 
and social benefits produced by salt production, thus, the objective of this research, was to evaluate the economic viability of Environmental Offsets as an alternative to the unoccupied PPAs in the saltworks.

\section{MATERIALS AND METHODS}

\section{Characterization of the study area}

The study was carried out on the north coast of Brazil, in the region known as White Coast between the coordinates $4^{\circ} 54^{\prime} 24$ ' and $5^{\circ} 10^{\prime} 18^{\prime \prime}$ south latitude and the meridians $37^{\circ} 18^{\prime} 08^{\prime \prime}$ and $37^{\circ} 02$ ' 12 " west longitude. This locality comprises the estuaries of the Apodi-Mossoró, PiranhasAçú and Galinhos Guamaré rivers, which together produce more than $95 \%$ of Brazilian salt (DINIZ \& VASCONCELOS, 2017).

The region is dominated by the oscillations of the Intertropical Convergence Zone, corresponding to the zone of collision between the humid air masses of the northern hemisphere and the southern hemisphere, responsible for the rainy and dry seasons (ROCHA et al., 2011), where the rainy season (EMPARN, 2011). The climate of this region is semiarid, type BSw'h' dry and very hot (according to the classification of KÖPPEN), whose rainfall the annual average $\left(<1,250 \mathrm{~mm} /\right.$ year $\left.^{-1}\right)$ is less than the potential evapotranspiration of the region $(1,500$ $1,600 \mathrm{~mm} /$ year $\left.^{-1}\right)$, being ideal for the production of sea salt in solar saltwoks (ROCHA et al., 2011).

The main sea currents bordering the study area are the Brazil Current, which accompanies the coast from Rio Grande do Norte (RN) to Rio Grande do Sul, north-south direction, with an average temperature of $22{ }^{\circ} \mathrm{C}$ and the Equatorial Current from Rio Grande do Norte to Amapá, with an eastwest direction and an average temperature of 25 ${ }^{\circ} \mathrm{C}$. These currents influence the climate around the Brazilian coast. The local tide is semidiurnal, where the average level (Z0) established is $139 \mathrm{~cm}$ above the RN (Reduction Level) with averages of prey of syllable of $234 \mathrm{~cm}$ above the RN, average of prearms of quadrature of $221 \mathrm{~cm}$, average of low-seas of sizígia of $43 \mathrm{~cm}$ below the RN and average of the low seas of squares of $56 \mathrm{~cm}$ (SILVEIRA et al., 2000).

\section{Productive areas and PPA occupancy}

The PPA soil use class of the Apodi / Mossoró river estuary was mapped on the basis of the definitions of PPA of the watercourse, with widths varying according to the estuary channel, as established by Federal Law No. 12.651 of May 25, 2012, better known as New Forest Code (Table 1).
The gutter dimensions of each section of the estuary were measured using images from the GeoEye-1 satellite, with a spatial resolution of $0.41 \mathrm{~m}$, and verified in the field. Images were georeferenced, vectored and then the corresponding PPA bands were generated. All process steps (georeferencing, vectorization and buffering) were performed with the free software QGIS version 2.8.

\section{Survey of productive areas and PPA occupancy}

For the study, only the saltworks industries that are installed in PPA were considered, with a total of 27 solar saltworks with productive areas in mangrove, apicuns and dunes. The evaluated saltworks agreed to participate in the study by assigning the random acronyms in order to preserve their trade names. The data related to the productive areas of each saline, as well as the respective PPAs occupied were obtained from the "Joint report on the environmental technical evaluation of the salt flats in the State of Rio Grande do Norte, Brazil" prepared by the Technical-Scientific- (GT-SAL, 2017), composed of representatives of the Brazilian Institute of Environment and Renewable Natural Resources (IBAMA) and the Institute of Sustainable Development and Environment of Rio Grande do Norte (IDEMA) (Table 1).

\section{Determination of environmental offsets}

In order to determine the value of environmental compensation, the criteria for assessment of non-mitigaFble environmental impacts established by Decree $n^{\circ} 6848 / 2009$ (Equation 1).

$\mathrm{EO}=\mathrm{VR} \times \mathrm{ID}$

Where:

$\mathrm{EO}=$ Value of Environmental Offsets;

ID = Impact Degree;

$\mathrm{VR}=$ Sum of the investments needed to implement the project.

In turn, the ID is the result of the sum of the estimated values for the enterprise, regarding Impact on Biodiversity (ISB), Commitment of Priority Area (CPA) and Influence on Conservation Units (ICU) and should not be higher than $0.50 \%$ (Equation 2).

$\mathrm{ID}=\mathrm{ISB}+\mathrm{CPA}+\mathrm{ICU}$

Where:

ID = Impact Degree;

ISB = Impact on Biodiversity;

$\mathrm{CPA}=$ Commitment of Priority Area;

$\mathrm{ICU}=$ Influence on Conservation Units.

The ISB counts the impacts of the enterprise directly on biodiversity in its area of direct and indirect influence, while the CPA accounts for the 
Table 1 - Saltworks productive areas and occupation of Permanent Preservation Areas (PPA) in estuarine systems, White Coast region, Brazil.

\begin{tabular}{lccc}
\hline Estuarine System & Saltworks numbers & Saltworks áreas (ha) & Occupation of PPA (ha) \\
\hline Apodi/Mossoró & 17 & $13,777.09$ & $1,077.32$ \\
Piranhas/Açú & 8 & $12,878.27$ & $1,089.93$ \\
Galinhos/Guamaré & 2 & $3,031.05$ & $1,117.23$ \\
Total & 27 & $29,686.41$ & $3,284.48$ \\
\hline
\end{tabular}

effects of the enterprise on the priority area in which it is inserted. The ISB and CPA values range from 0 to $0.25 \%$ and are calculated based on the indices in the said Decree.

The values adopted for each index used in the calculation of the Saltworks Impact Degree, as well as their respective justifications, are listed in table 2. In cases where there were doubts as to the most appropriate attribute to fit the project, it was decided to attribute of higher value, always based on the precautionary principle. These indices are established by Decree $n^{\circ} 6848 / 2009$, which assigns a range of values to each specific index. Thus, when opting for a value within this predetermined range, we must justify why we chose it.

The values were defined for each index used in the calculation of environmental compensation, followed by calculating the ISB (Equation 3) and CAP (Equation 4).
$\mathrm{ISB}=\mathrm{MI}^{*} \mathrm{BI}^{*}(\mathrm{CI}+\mathrm{TI}) / 140$

$\mathrm{CPA}=\mathrm{MI}^{*} \mathrm{ICAP}^{*} \mathrm{TI} / 70$

In relation to Influence in Conservation Units (IUC), 0 (zero) was adopted, the projects are not located in the vicinity of conservation units or in their buffer zone.

As for the sum of the investments needed to implement the project (VR) for the projects in this study, the direct comparative method of market data was used, reaching the amount of US\$ $10,309.28$ per hectare in each saltwork evaluated.

The Economic Impact caused by the PPA eviction was estimated based on the perpetual flow of revenue losses, using the Net Present Value (NPV), adapted from SILVA \& FONTES (2005), and the interest rate was adopted according to the Long Term Rate (TLP) of 7\%, in force in the country (Equation 5).

$\mathrm{NPV}=\sum_{j=0}^{n} R_{j}(1+i)^{-j}-\sum_{j=0}^{n} C_{j}(1+i)^{-j}$

Table 2 - Indices adopted for determining the Impact Degree of saltworks industry: Magnitude Index (MI), Biodiversity Index (BI) Coverage Index (CI) Temporality Index (TI) and Impairment of Priority Area Index (ICAP).

\begin{tabular}{|c|c|c|c|c|}
\hline Index ${ }^{*}$ & $\begin{array}{l}\text { Minimum and } \\
\text { maximum values }\end{array}$ & $\begin{array}{l}\text { Adopted } \\
\text { value }\end{array}$ & Attributes & Justification \\
\hline MI & $0-3$ & 3 & $\begin{array}{l}\text { Average of the negative environmental } \\
\text { impact in relation to the compromise of } \\
\text { environmental resources. }\end{array}$ & $\begin{array}{l}\text { According to IBAMA, the extraction of sea } \\
\text { salt (mineral extraction) has high polluting } \\
\text { potential. }\end{array}$ \\
\hline BI & $0-3$ & 3 & $\begin{array}{l}\text { Area of transit, or, reproduction of } \\
\text { species considered endemic, or, } \\
\text { threatened with extinction. }\end{array}$ & $\begin{array}{l}\text { The saltworks are inserted in estuarine } \\
\text { regions, an area of great relevance for the } \\
\text { conservation of aquatic fauna and flora. }\end{array}$ \\
\hline $\mathrm{CI}$ & $1-4$ & 1 & $\begin{array}{l}\text { Impacts limited to the area of a } \\
\text { watershed. }\end{array}$ & $\begin{array}{l}\text { The project's impacts are restricted to the } \\
\text { estuary. }\end{array}$ \\
\hline TI & $1-4$ & 4 & $\begin{array}{l}\text { Long: more than } 30 \text { years after the } \\
\text { installation of the project. }\end{array}$ & $\begin{array}{l}\text { The occupation of the area by the enterprise } \\
\text { can last hundreds of years. }\end{array}$ \\
\hline ICAP & $0-3$ & 3 & $\begin{array}{l}\text { Impacts affecting areas of extremely high } \\
\text { biological importance or classified as } \\
\text { insufficiently known. }\end{array}$ & $\begin{array}{c}\text { According to the Map of Priority Areas of } \\
\text { the Ministry of the Environment, the Apodi/ } \\
\text { Mossoro River estuary has "Extremely } \\
\text { High" priority. }\end{array}$ \\
\hline
\end{tabular}

According to Decree n. 6,848 / 2009 (BRASIL, 2009).

Ciência Rural, v.50, n.5, 2020. 
Where:

$\mathrm{Rj}=$ current value of revenues;

$\mathrm{Cj}=$ value of revenue after area vacancy;

$\mathrm{i}=$ interest rate;

$\mathrm{j}=$ period in which revenues or unemployment occur; $\mathrm{n}=$ number of periods or duration of the project.

It was considered that EO was feasible whenever the costs resulting from it were lower than the economic impact caused by the vacancy of the PPAs.

\section{RESULTS AND DISCUSSION}

\section{Saltwork productive area versus PPA occupation}

The average productive area of the saltwork enterprises was $1,099.50$ ha, with a minimum of 69.00 and a maximum of 5,539.90 ha (Table 3). Considering the form of salt exploration and harvest, according to ROCHA et al. (2012) all the evaluated salt was considered industrial and mechanized.

On average, $13.70 \%$ of the productive area of the saltworks is installed in PPA, ranging from the minimum value of $1.06 \%$ to the maximum of $46.91 \%$. Although, some saltworks occupied large areas of permanent preservation, the vast majority of these occupations do not exceed $10 \%$. In order to understand why the occupation of PPAs by the saltworks it is necessary to emphasize that this occupation, in the great majority of cases, occurred decades and even centuries before the appearance of the PPA concept itself (DINIZ et al., 2015), and that most of the salt flats that are now in use were built in areas along the watercourses that were periodically flooded by the tides, where the formation of sodium chloride naturally occurred (COSTA et al., 2014). In addition, priority was given to the layout of the salt

Table 3 - Saltworks, productive area (ha), occupation of Permanent Preservation Areas - PPA - (ha) and percentage of PPA occupied (\%) by saltworks in the region of White Coast, Brazil.

\begin{tabular}{|c|c|c|c|}
\hline Saltworks ${ }^{*}$ & Productive area (ha) & Occupation of PPA (ha) & Occupation of PPA (\%) \\
\hline GUA & $1,663.46$ & 80.86 & 4.86 \\
\hline FME & $2,951.78$ & 60.37 & 2.05 \\
\hline MIR & $1,668.69$ & 188.84 & 11.32 \\
\hline SLM & 494.92 & 75.81 & 15.32 \\
\hline SVE & 156.50 & 24.16 & 15.44 \\
\hline MBO & 480.00 & 37.68 & 7.85 \\
\hline MAR & $1,023.21$ & 33.62 & 3.29 \\
\hline CEA & 232.25 & 15.57 & 6.70 \\
\hline SCA & 725.92 & 10.16 & 1.40 \\
\hline STA & $1,087.68$ & 31.71 & 2.92 \\
\hline SVEII & 69.00 & 5.49 & 7.96 \\
\hline RSO & 153.71 & 14.40 & 9.37 \\
\hline SLMII & 303.37 & 58.58 & 19.31 \\
\hline AGS & 115.25 & 38.73 & 33.61 \\
\hline UPU & $1,842.00$ & 38.79 & 2.11 \\
\hline PED & 722.32 & 338.86 & 46.91 \\
\hline MAL & 87.03 & 23.69 & 27.22 \\
\hline CTA & 260.25 & 2.76 & 1.06 \\
\hline ARA & $1,000.09$ & 249.81 & 24.98 \\
\hline IMB & $3,265.62$ & 280.57 & 8.59 \\
\hline UMA & 565.85 & 64.69 & 11.43 \\
\hline SOR & $5,539.90$ & 226.86 & 4.10 \\
\hline SLP & $1,318.29$ & 166.95 & 12.66 \\
\hline SLE & 224.05 & 19.96 & 8.91 \\
\hline SAR & 704.22 & 78.33 & 11.12 \\
\hline CAM & 360.00 & 115.39 & 32.05 \\
\hline ANE & $2,671.05$ & $1,001.84$ & 37.51 \\
\hline
\end{tabular}

*Acronyms randomly assigned to saltworks. 
pans as close as possible to the estuary margin, to enable the shipment of salt and the flow of water/sea production, thus providing a technical, logistical and economic justification for the practice.

\section{Environmental offsets}

The ID calculated for all the enterprises evaluated was $0.83 \%$; however, decree $6.848 / 2009$ set the maximum value for this variable at $0.50 \%$. Difference between the calculated ID and the maximum ID set by the legislation resulted in the loss of US\$ $1,008,950.03$ from the value of $\mathrm{EO}$, which in practice implies fewer resources for nature conservation (Table 4). The definition of a maximum limit for the GI is one of the most controversial points of the method of calculation of environmental offsets, and has been questioned by several environmental groups, since in determining a "ceiling" for the impacts of an enterprise, the principle of proportionality between the environmental damage and the corresponding remedial action (ALMEIDA \& PINHEIRO, 2011).

It is important to highlight the high weight that is given to the VR of the project in the calculation of the EO, which can sometimes stand out due to the environmental impact caused by it. As an example, we can mention the SMA saltwork, whose PPA occupation is 33.62 ha, but the value referring to EO is higher than that of the ARA saltwork, occupying almost 250 ha, simply because the SMA saltwork has a VR higher.

\section{Economic impact of unemployment of PPA}

The economic impact due to the vacancy of the PPA by the saltworks was estimated at US\$ $3,258.88 /$ ha. The total vacancy of PPAs in the saltworks would result in a combined revenue

Table 4 - Reference Value and Environmental Ofssets calculated for the saltworks industries of the Brazilian White Coast region based on the Impact Degree (ID).

\begin{tabular}{|c|c|c|c|}
\hline Saltworks & Reference value of saltworks (US\$) & $\begin{array}{l}\text { Environmental Ofssets US\$ } \\
\qquad(\mathrm{ID}=0.83 \%)\end{array}$ & $\begin{array}{l}\text { Environmental Ofssets US\$ } \\
\qquad(\mathrm{ID}=0.50 \%)\end{array}$ \\
\hline GUA & $17,149,072.16$ & $142,337.29$ & $85,745.36$ \\
\hline FME & $30,430,721.64$ & $252,574.98$ & $152,153.61$ \\
\hline MIR & $17,202,989.98$ & $142,784.81$ & $86,014.95$ \\
\hline SLM & $5,102,268.04$ & $42,348.82$ & $25,511.34$ \\
\hline SVE & $1,613,402.06$ & $13,391.24$ & $8,067.01$ \\
\hline $\mathrm{MBO}$ & $4,961,240.31$ & $41,178.29$ & $24,806.20$ \\
\hline MAR & $10,575,813.95$ & $87,779.25$ & $52,879.07$ \\
\hline CEA & $2,400,516.79$ & $19,924.29$ & $12,002.58$ \\
\hline SCA & $7,503,049.09$ & $62,275.31$ & $37,515.25$ \\
\hline STA & $11,242,170.54$ & $93,310.02$ & $56,210.85$ \\
\hline SVEII & $713,178.29$ & $5,919.38$ & $3,565.89$ \\
\hline RSO & $1,588,733.85$ & $13,186.49$ & $7,943.67$ \\
\hline SLMII & $3,135,607.24$ & $26,025.54$ & $15,678.03$ \\
\hline AGS & $1,191,214,47$ & $9,887.08$ & $5,956.07$ \\
\hline UPU & $19,038,759.68$ & $158,021.70$ & $95,193.79$ \\
\hline PED & $7,465,839.79$ & $61,966.47$ & $37,329.19$ \\
\hline MAL & $899,534.88$ & $7,466.14$ & $4,497.67$ \\
\hline CTA & $2,689,922.48$ & $22,326.36$ & $13,449.61$ \\
\hline ARA & $10,336,589.15$ & $85,795.83$ & $51,684.24$ \\
\hline IMB & $33,753,178.29$ & $280,151.38$ & $168,765.89$ \\
\hline UMA & $5,848,578.81$ & $48,543.20$ & $29,242.89$ \\
\hline SOR & $57,259,948.32$ & $475,257.57$ & $286,299.74$ \\
\hline SLP & $13,625,736.43$ & $113,093,61$ & $61,151.93$ \\
\hline SLE & $2,315,762.27$ & $19,220.83$ & $11,578.81$ \\
\hline SAR & $7,278.76$ & $60,413.71$ & $36,393.79$ \\
\hline CAM & $3,720,930,23$ & $30,883.72$ & $18,604.65$ \\
\hline ANE & $27,607,751.93$ & $593,366.36$ & $35,668.93$ \\
\hline TOTAL & $306,836,279.07$ & $2,546,741.11$ & $1,553,181.39$ \\
\hline
\end{tabular}

Ciência Rural, v.50, n.5, 2020. 
loss of US\$ 99,744,624.45 The lowest economic impacts were comprised between a minimum of US\$ $81,296.02$ related to the vacancy of 2.76 ha of PPA by CTA saltwork, and the maximum of US\$ $29,509,278.35$ related to unemployment of a range of 1,001.84 ha of PPA by ANE saltwork. For all the enterprises evaluated, the value corresponding to EO was several times smaller than the economic impact resulting from the vacancy of the PPA (Table 5).

It is important to emphasize that the vacancy of the PPA by the evaluated saltworks will influence not only the production of sea salt, but all the socioeconomic factors inherent in the salt industry, since the perpetual flow of the loss of revenue reaches a relevant amount, even surpassing the Gross Domestic Product of Rio Grande do Norte State in 2017. In addition, the reduction, proportional to the productive area of saltworks, in the collection of Tax on Circulation of Goods and Services (TCGS), should be considered, and this reduction should be understood as a measure of the social and environmental cost of PPA unemployment, with a reduction in employment, as well as the benefits of tax collection.

From a more detailed analysis, it is observed that lower TCGS tax collection will also result in a lower allocation of resources to environmental actions, since according to LOPES et al. (2012), of the $25 \%$ of TCGS collected and distributed among municipalities, $0.5 \%$ will be allocated to conservation units and other protected areas.

Since the settlement of PPAs by saltworks in the White Coast region will cause economic and social damages (BEZERRA et al., 2012), and conversely, the permanent environmental damages resulting from this occupation are not subject to mitigation, since they provided soil salinization in these areas; and therefore, prevented the growth of mangrove vegetation in these areas, EO has shown

Table 5 - Economic Impact (US\$) resulting from the vacancy of the PPA by the Environmental Offsets (US\$) estimate.

\begin{tabular}{|c|c|c|}
\hline Salworks & Economic Impact (US\$) & $\begin{array}{l}\text { Environmrntal Offsets (US\$) } \\
\qquad \mathrm{ID}=0.50 \%\end{array}$ \\
\hline GUA & $2,387,892.21$ & $85,966.92$ \\
\hline FME & $1,780,214.10$ & $152,546.77$ \\
\hline MIR & $5,576,670.36$ & $86,237.20$ \\
\hline SLM & $2,238,759.68$ & $25,557.26$ \\
\hline SVE & $713,473.61$ & $8,087.86$ \\
\hline $\mathrm{MBO}$ & $1,112,735.32$ & $24,806.20$ \\
\hline MAR & $992,838.68$ & $52,362.27$ \\
\hline CEA & $459,800.66$ & $112,002.58$ \\
\hline SCA & $300,036.91$ & $37,515.24$ \\
\hline STA & $936,434.11$ & $56,210.85$ \\
\hline SVEII & $162,126.24$ & $3,565.89$ \\
\hline RSO & $425,249.17$ & $7,943.66$ \\
\hline SLMII & $1,729,837.24$ & $15,678.03$ \\
\hline AGS & $1,143,742.89$ & $5,956.07$ \\
\hline UPU & $1,148,098.93$ & $95,193.79$ \\
\hline PED & $10,006,939.83$ & $37,329.19$ \\
\hline MAL & $699,593.94$ & $4,497.67$ \\
\hline CTA & $81,506.09$ & $13,449.51$ \\
\hline ARA & $7,377,187.15$ & $51,684.23$ \\
\hline IMB & $8,285,566.63$ & $168,765.89$ \\
\hline UMA & $1,910,372.83$ & $29,242.89$ \\
\hline SOR & $6,699,446.28$ & $286,299.74$ \\
\hline SLP & $4,930,232.55$ & $68,128.68$ \\
\hline SLE & $589,442.59$ & $11,578.81$ \\
\hline SAR & $2,313,178.29$ & $36,393.79$ \\
\hline CAM & $36,393.79$ & $18,604.65$ \\
\hline ANE & $29,585,529.71$ & $138,038.76$ \\
\hline
\end{tabular}

Ciência Rural, v.50, n.5, 2020. 
to be economically feasible, since its total value, considering the 27 saltworks evaluated, was about 60 times smaller than the economic impacts resulting from the vacancy of the PPA. Another point that deserves to be mentioned for the decision making regarding EO or vacating the PPA relates to the real environmental gains of the retreat of these areas by the saltworks, because according to COSTA et al. (2013) the soil of the areas where the salt is installed is not suitable for the development of vascular vegetation, especially the mangrove, which does not tolerate the high salt content present in the soil. It would; therefore, be unlikely that, once they were unoccupied, these areas would once again recover and perform their ecosystem functions.

In this way, in addition to representing a lower economic cost, EO gives the possibility that an environmental area equivalent to degraded area can be improved to reach the best result in terms of ecosystem services (HEYES \& MORRISONSAUNDERS, 2012), especially in cases of application of resources in Conservation Unit, ensuring positive results for the environment (EPA, 2006). The EO has been praised as a tool to provide a more flexible and economical approach to development, while achieving better environmental results (TEN et al., 2004). It has also been suggested that the EO could guarantee to the enterprises greater speed to obtain licensing for operation (ICMM, 2005).

How many stages and actors of the EO process, this begins in the licensing, when the licensing body, makes the valuation of the amount of compensation to be paid by the entrepreneur. Subsequently, the Federal Environmental Compensation Committee - CCAF, assumes the task of allocating these resources to the affected Units. Only then, the ICMBio are transferred to the management organs of the conservation units, in order to be executed in accordance with the actions listed in Article 33 of Decree 4.340/2002. The destination, in turn, becomes the most important step in the direction: compensated damage $=$ gain in conservation (increase in protection level, improvement of ecological processes, increase of environmental awareness and etc), since it is time is based on information to give the most strategic destination for resources (SCHAEFFER-NOVELLI et al., 2012).

However, BECHARA (2009) argued that EO can not be understood as an "authorization to pollute", but rather must be taken as an instrument capable of compatible development and environmental protection. Corroborating this statement, MEISTER \& SALVIATI (2009) believe that a public policy or even private initiative that considers only economic factors will not solve socioenvironmental problems, requiring an integrated action by the three spheres of government.

Many of the natural resources that serve as a basis for economic activities depend in some way on ecological systems which in turn produce a variety of services and the reckless use of these resources can irreversibly reduce their carrying capacity and of resilience, affecting along the chain, the own economic development. Thus, economic activities need to be designed to provide the right incentives to protect the resilience of natural systems (SANTOS \& SILVA, 2012). In this context, the MILLENNIUM ECOSYSTEM ASSESSMENT (2005) defines ecological services, or environmental services, as the benefits that man obtains from ecosystems.

It is known that the areas of PPAs occupied by salinas were originally composed of mangroves and apicunas, ecosystems recognized by directly and indirectly providing innumerable ecological services, such as fishing, carbon fixation, protection against erosion, among others (SCHAEFFER-NOVELLI et al., 2012). Knowing the importance of the mangroves and apicuns of the region and being of common census that the occupation of these areas can negatively affect these ecosystems, it is indispensable that the resources coming from the EO are directed to the creation and maintenance of Conservation Units in areas (ALMEIDA \& PINHEIRO, 2011). This is the first step in reducing the burden on the environment and the community, thus establishing a reconciliation between environmental protection and economic development.

Thus, it is essential to highlight the significant difference between Environmental Offsets (article 36 of Law 9.985/2000) and "financial compensation", since in the first the entrepreneur becomes responsible for promoting actions that result in improvement of environmental quality (MOTA, 2015). In this regard, SÁNCHEZ (2008) warns that, for the ecological effectiveness of Environmental Offsets, the resources generated, should be used to create or maintain Conservation Units in the region of influence of the enterprises, in order to socially distribute the impacts (positive and negative) of the project, preventing or minimizing tensions between companies and local populations. Communities do not realize the gains from ecosystem services if the resource invested takes place in an area more than $200 \mathrm{~km}$ away (IUCN, 2012).

It is noteworthy; although, the evaluation of government policies must be stimulated, since it generates knowledge of the implemented policies 
results, which allows the rulers to use this information to improve the conception or implementation of actions, to base decisions and to promote the provision of information. accounts. In this sense, the indicators are instruments that allow identifying and measuring the results of an intervention, as well as understanding the causes and effects of the results obtained from a theoretical conception (RAMOS $\&$ SCHABBACH, 2012). Within the context of public policy evaluation, the primary purpose of the indicator is to measurably translate a certain aspect of a government action, allowing it to evaluate its results and, from there, reorient the actions, which suggested their indispensability to qualify environmental offsets (BANCO MUNDIAL, 2004).

In addition, these indicators make it possible to adapt such compensation to new global environmental agreements and policies, such as 2030 Agenda, specifically in the objectives and goals of SDG8, SDG9, SDG13, SDG15 that address: promoting sustainable economic growth; promote sustainable and inclusive industrialization; take urgent action to combat climate change and its impacts, protect, restore and promote sustainable use of terrestrial ecosystems, sustainably manage forests, combat desertification, halt reverse land degradation and biodiversity loss (ONU, 2015).

Therefore, it appears, it can be said that EO is an alternative to vacating PPA by the saltwork sector. In addition, environmental offsets can be an important mechanism for financing Conservation Units in Rio Grande do Norte State, since the state has only seven Conservation Units, and only the Sustainable Development Reserve of Ponta do Tubarão covers coastal ecosystems (CNIP, 2018), and thus ensures that environmental compensation does not deviate from its true purpose, which is to counterbalance environmental losses, and not to generate financial resources (BECHARA, 2009).

\section{CONCLUSION}

Environmental Offsets is an economically viable and more attractive alternative to the vacancy of PPAs by the saltworks industry and can also provide environmental gains as a result of the financing of Conservation Units in the areas of influence of the enterprises.

There is evidence of the need to improve the current method used to estimate the value of Environmental Offsets, since, when setting a maximum compensation limit, the reality of the environmental impacts caused by the projects is not reflected, and the collection of resources for the creation and maintenance of Brazilian Conservation Units.

Thus, future studies should establish method enlargement capable of economically valuing permanent preservation areas based on their ecosystem services, since in some offsets adopted, until then, only one service is valued, while in others there is a combination of several of them. Moreover, such methods may help to communicate and understand the importance of these ecosystems, as well as foster financial sustainability strategies and public policies.

\section{ACKNOWLEDGEMENTS}

The authors would like to thank the Programa de Pós-Graduação em Ciência Animal da Universidade Federal Rural do Semi-Árido and to the Coordenação de Aperfeiçoamento de Pessoal de Nível Superior (CAPES), Brasil, for the logistical and operational support for the development of this research.

\section{DECLARATION OF CONFLICT OF INTERESTS}

The authors declared no potential conflicts of interest with respect to the research, authorship, and/or publication of this article.

\section{AUTHORS' CONTRIBUTIONS}

The authors contributed equally to the manuscript.

\section{REFERENCES}

ALMEIDA, P. P.; PINHEIRO, A. C. D. The amount of environmental compensation. Revista de Direito Público, v.6, n.3, p.39-52, 2011. Available from: <http://www.uel.br/revistas/ uel/index.php/direitopub/article/viewFile/9565/9068>. Accessed: Nov. 12, 2018.

ALONGI, D. M. Energetics of mangroves Forests. New York: Springer Netherlands, 2009.

BARBIER, E. B. Valuing ecosystem services as productive inputs. Economic Policy, Oxoford, v.22, n.49, p.177-229, 2007. Available from: <http://earthtek.org/EVPP524/ProdFunc_Barbier2007EP. pdf $>$. Accessed: Nov. 22, 2018.

BARBOSA, F. M. A. et al. Status and distribution of mangroves in Mozambique. South African Journal of Botany, v.67, n.3, p.393- 398, 2001. Available from: <https://core.ac.uk/download/ pdf/82060861.pdf>. Accessed: Nov. 22, 2018. doi: 10.1016/ S0254-6299(15)31155-8.

BECHARA, E. Licenciamento e compensação ambiental na Lei do Sistema Nacional das Unidades de Conservação (SNUC). São Paulo: Ed. Atlas, 2009.

BEZERRA, J. M. et al. Economic and environmental aspects of the salting operation in Rio Grande do norte. Engenharia Ambiental, v.9, n.2, p.003-020, 2012. Available from: <http://ferramentas. 
unipinhal.edu.br/engenhariaambiental/viewarticle.php?id=659\&la yout $=$ abstract\&locale=en $>$. Accessed: Nov. 22, 2018.

BORN, R. H.; TALOCCHI, S. Compensações por Serviços Ambientais: sustentabilidade ambiental com inclusão social. In: BORN, R. H.; TALOCCHI, S. (orgs.). Proteção do capital social e ecológico: por meio de Compensações por Serviços Ambientais (CSA). São Paulo: Peirópolis, p.27-45, 2002. Available from: <https://books.google.com.br/books?hl=pt-BR $\& 1 \mathrm{r}=\& \mathrm{id}=\mathrm{B} 66 \mathrm{WORWhiM} 4 \mathrm{C} \& \mathrm{oi}=\mathrm{fnd} \& \mathrm{pg}=\mathrm{PA} 27 \&$ ots $=\mathrm{LidM}$ TLRv7Y\&sig=zMijaMnfO0CYPKb0QLQz7YN4x7E\&redir $\mathrm{esc}=\mathrm{y} \# \mathrm{v}=$ onepage $\& \mathrm{q} \& \mathrm{f}=$ false $>$. Accessed: Nov. 20, 2018

BRASIL. Lei $n^{\circ} 12.651$, de 25 de Maio de 2012. Dispõe sobre a proteção da vegetação nativa; altera as Leis $n^{\circ} 6.938$, de 31 de agosto de 1981, 9.393, de 19 de dezembro de 1996, e 11.428, de 22 de dezembro de 2006; revoga as Leis nos 4.771, de 15 de setembro de 1965 , e 7.754, de 14 de abril de 1989, e a Medida Provisória no 2.166-67, de 24 de agosto de 2001; e dá outras providências. Diário Oficial da União, Brasília, 28 mai. 2012. Available from: $<$ http://www.planalto.gov.br/ccivil_03/_ato2011-2014/2012/lei/ 112651.htm>. Accessed: Nov. 20, 2017.

BRASIL. Decreto $n^{0} \mathbf{6 . 8 4 8}$, de 14 de maio de 2009. Altera e acrescenta dispositivos ao Decreto no 4.340 , de 22 de agosto de 2002, para regulamentar a compensação ambiental. Available from: <http://www.planalto.gov.br/ccivil_03/_Ato2007-2010/2009/ Decreto/D6848.htm>. Accessed: Nov. 20, 2017.

CAMPHORA, A. L.; MAY, P. H. A valoração ambiental como ferramenta de gestão em unidades de conservação: há convergência de valores para o bioma Mata Atlântica? Megadiversidade, v.2, n.1-2, p.24-38, 2006. Available from: <https://www.researchgate. net/publication/242773934_A_valoracao_ambiental_como_ ferramenta_de_gestao_em_unidades_de_conservacao ha convergencia_de_valores_para_o_bioma_Mata_Atlantica $>$. Accessed: Nov. 22, 2018

COSTA, D. F. S. et al. Brief characterization about the historical evolution of the salt production activities in Rio Grande do Norte state's (Brazil). Sociedade e Natureza, v.25, n.1, p.21-34, 2013. Available from: <http://www.redalyc.org/ pdf/3213/321327372003.pdf $>$. Accessed: Nov. 22, 2018. doi: $10.1590 / \mathrm{S} 1982-45132013000100003$

COSTA, D. F. S. et al. 2014. Phytoecological analysis and zonation of mangrove of the hypersaline estuary. Mercator, v.13, n.1, p.119-126. Available from: <https://www.redalyc.org/ pdf/2736/273630615010.pdf $>$. Accessed: Oct. 15, 2018. doi: 10.4215/RM2014.1301. 0009 .

COELHO, F. N.; LINHARES, M. A. S. Compensação ambiental aplicada na arborização urbana da cidade de Vitória - ES. Revista da Sociedade Brasileira de Arborização Urbana, v.1, n.1, p.4555, 2006. Available from: <https://revistas.ufpr.br/revsbau/article/ view/66514>. Accessed: Nov. 20, 2018. doi: 10.5380/revsbau. v1i1.66514.

DAVIS, J. Structure, function, and management of the biological system for seasonal solar saltworks. Global NEST Journal, v.2, n.3, p.217-226, 2000. Available from: <https://journal.gnest.org/ sites/default/files/Journal\%20Papers/davis.pdf $>$. Accessed: Nov. 22,2018 .

DINIZ, M. T. M.; VASCONCELOS, F. P. Natural conditions for the sea salt production in Brazil. Mercator, Fortaleza, v.16, e1613b, 2017. Available from: <http://www.scielo.br/pdf/ mercator/v16/1984-2201-mercator-16-e16013.pdf>. Accessed: Nov. 18, 2018. doi: 10.4215/rm2017.e16013.

DINIZ, M. T. M.; VASCONCELOS, F. P.; MARTINS, M. B. 2015. Inovação tecnológica na produção brasileira de sal marinho e as alterações sócioterritoriais dela decorrentes: uma análise sob a ótica da teoria do empreendedorismo de Schumpeter. Sociedade e Natureza, v.27, n.3, p.421-438. Available from: $<$ http://www.scielo. br/scielo.php? pid=S1982-45132015000300421\&script $=$ sci abstract\&tlng=pt $>$. Accessed: Nov. 20, 2018. doi: 10.1590/1982451320150305

EMPARN - Empresa de Pesquisa Agropecuária do Rio Grande do Norte. 2011. Dados de Precipitação Anual. Available from: $<$ http://www.emparn.rn.gov>. Accessed: Jan. 28, 2018.

EPA, Environmental Protection Authority. Environmental offsets position statement no 9, Perth: Environmental Protection Authority, 2006. Available from: <https://www.supremecourt. wa.gov.au/files/05_EPA_Position_Statement_No.\%209_ Environmental Offsets.pdf $>$. Accessed: ${ }_{-}$Oct. 17, $201 \overline{8}$

GT-SAL. Grupo Técnico de Trabalho para Regularização dos Empreendimentos Salineiros. Relatório ambiental dos empreendimentos estado do Rio Grande do Norte. Mossoró: GTSAL, 2017. 176p. Available from: <http://www.idema.rn.gov. br/Conteudo.asp?TRAN=ITEM $\&$ TARG $=144940 \& A C T=\& P A G E$ $=0 \& \mathrm{PARM}=\& \mathrm{LBL}=$ Documentos $+\mathrm{T} \% \mathrm{E} 9 \mathrm{cnicos}>$. Accessed: Nov. 20,2017

HEYES, N.; MORRISON-SAUNDERS, A. Effectiveness of environmental offsets in environmental impact assessment: practitioner perspectives from Western Australia. Impact Assessment and Project Appraisal, v.25, n.3, p.209-218, 2012. Available from: <https://www.sciencedirect.com/science/article/ abs/pii/S0006320718306906?dgcid=rss_sd_all>. Accessed: Nov. 21, 2018. doi: 10.3152/146155107X227126.

ICMM, International Council on Mining and Metals. Biodiversity offsets: a proposition paper, London: ICMM. 2005.

LEE, S. Y.; et al. Ecological role and services of tropical mangrove ecosystems: a reassessment. Global Ecology and Biogeography, v.23, n.7, p.726-743, 2014. Available from: $<$ https://onlinelibrary. wiley.com/doi/abs/10.1111/geb.12155>. Accessed: Nov. 21, 2018. doi: $10.1111 /$ geb. 12155 .

LOPES, L. S.; et al. Economic and social viability of a project to reforest the area of permanent preservation (APP) of Cataguarino. Revista de Política Agrícola, v.21, n.1, p.22-37, 2012. Available from: $\quad<$ https://www.embrapa.br/busca-de-publicacoes/-/ publicacao/930801/estudo-da-viabilidade-economico-socialde-um-projeto-de-reflorestamento-da-area-de-preservacaopermanente-app-de-cataguarino>. Accessed: Nov. 20, 2018.

MEISTER, K.; SALVIATI, V. O investimento privado e a restauração da Mata Atlântica no Brasil. Revista Intertox de Toxicologia, Risco Ambiental e Sociedade, v.2, n.2, p.43-57, 2009. Available from: $<\mathrm{http}: / / \mathrm{www}$. revistarevinter.com.br/autores/ index.php/toxicologia $>$. Accessed: Nov. 19, 2018.

Millenium Ecosystem Assessment. 2005. Ecosystems and human wellbeing: synthesis. Island Press, Washington DC. Available from: $<\mathrm{http}$ ://www.millenniumassessment.org/documents/document.356. aspx.pdf $>$. Accessed: Sep. 22, 2018. 
MOTA, M. The function of social environmental property: the environmental compensation as a result of principle of paying user. Revista de Direito da Cidade, v.7, n.2, p.776-803, 2015. Available from: <https://www.e-publicacoes.uerj.br/index.php/ rdc/issue/view/1030>. Accessed: Nov. 20, 2018. doi: 10.12957/ rdc. 2015.16950 .

NAGELKERKEN, I. et al. The habitat function of mangroves for terrestrial and marine fauna: a review. Aquatic Botany, v.89, p.155-185, 2008. Available from: <https://pdfs. semanticscholar.org/4091/26a02ea4413ae47bd8dc2ba1ffa 695de2b0e.pdf $>$. Accessed: Nov. 16, 2018. doi: 10.1016/j. aquabot.2007.12.007.

ONU - ORGANIZAÇÃO DAS NAÇÕES UNIDAS. 2015 Transformando Nosso Mundo: A Agenda 2030 para o Desenvolvimento Sustentável. Available from: <https:// nacoesunidas.org/pos2015/agenda2030/>. Accessed: Nov. 26, 2019.

RAMOS, M. P.; SCHABBACH, L. M. The state of the art of public policy evaluation: concepts and examples of evaluation in Brazil. Rio de Janeiro: Revista de Administração Pública, 2012. Available from: <http://bibliotecadigital.fgv.br/ojs/index.php/rap/ article/view/7140/5692>. Accessed: Oct. 17, 2018.

ROCHA, A. P. B.; et al. 2011. Geoambientes, uso e ocupação do espaço no estuário do rio Apodi-Mossoró, Rio Grande do Norte, Nordeste do Brasil. Revista Eletrônica do Prodema, v.7, n.2, p.60-75. 2011. Available from: <http://www.revistarede.ufc.br/ rede>. Accessed: Oct. 15, 2018

ROCHA, R. M. et al. Brazilian solar saltworks - ancient uses and future possibilities. Aquatic Biosystems, v.8, n.8, p.16, 2012. Available from: <https://www.ncbi.nlm.nih.gov/ pubmed/22490329>. Accessed: Sep. 19, 2018.

SÁNCHEZ, L. E. Avaliação de impacto ambiental: conceitos e métodos. São Paulo: Oficina de Textos, 2008. 495p.

SANTOS, M. J. L. F.; LEITE, R. A. O conceito de utilidade pública aplicado ao setor salineiro e a controvérsia envolvendo a autorização para supressão de Áreas de Preservação Permanente - manguezais. Revista Direito Ambiental e Sociedade, v.1, n.1. p.389- 408, 2011. Available from: <http://www.publicadireito. com.br/conpedi/manaus/arquivos/anais/fortaleza/3236.pdf $>$. Accessed: Nov. 22, 2018

SANTOS, R. C.; SILVA, I. R. Ecosystem services provided by the beaches of Camaçari City, Northen Coast of the State of Bahia, Brazil. Cadernos de Geociências, v.9, n.1, P.47-56, 2012.
Available from: <https://repositorio.ufba.br/ri/bitstream/ri/6882/1/ AA.pdf $>$. Accessed: Nov. 19, 2018.

SCHAEFFER-NOVELLI, Y. et al. Alguns impactos do PL 30/2011 sobre os Manguezais brasileiros. In: Souza, G.; Jucá, K.; Wathely, M. (Orgs.). Código Florestal e a Ciência: O que nossos legisladores ainda precisam saber. 2012. Available from: $<\mathrm{http}$ :/ www.mpsp.mp.br/portal/page/portal/cao_criminal/Boas_praticas/ Relacao Projetos/projetoflorestar1/revista codigo florestal e a ciencia.pdffile://C:/Users/ferna/Downloads/revista_codigo_ florestal e a ciencia-wwf\%20(1).pdf>. Accessed: Nov. 17, 2017.

SIESAL. Sindicato da Indústria da Extração do Sal no Estado do Rio Grande do Norte. Atas das assembléias ordinárias. Mossoró, Rio Grande do Norte, 2016.

SILVA, M. L.; FONTES, A. A. Discussion on the criteria of economical evaluation: net present value (VPL), equivalent annual value (VAE) and soil expected value (VET). Revista Árvore, v.29, n.6, p.931-936, 2005. Available from: <http://www.scielo. br/pdf/rarv/v29n6/a12v29n6.pdf >. Accessed: Nov. 22, 2018. doi: 10.1590/S0100-67622005000600012.

SILVEIRA, I. C. A. et al. 2000. The Brazil current off the Eastern Brazilian Coast. Revista Brasileira de Oceanografia, v.48, n.2, p.171-183. Available from: <http://www.scielo.br/scielo php? script $=$ sci_arttext $\&$ pid $=$ S $1413-77392000000200008>$. Accessed: Oct. 19, 2018. doi: 10.1590/S1413-77392000000200008.

TEN K. K.; et al. Biodiversity Offsets: Views, Experience and the Business Case. Gland Switzerland and Cambridge, UK: IUCN. London: Insight Investmen. 2004.

TRINDADE, S. L. T.; ALBUQUERQUE, G. J. Subsídios para o Estudo da história do Rio Grande do Norte. $2^{\circ}$ ed. Natal: Sebo Vermelho, 2005.

VITA, S.; et al. Early chemistry techniques as described in the chronicles written by travelling naturalists who explored colonial and imperial Brazil. Química Nova, v.30, n.5, p.1381-1386, 2007. Available from: <http://quimicanova.sbq.org.br/imagebank/pdf/ Vol30No5 1381 54-AG06466.pdf>. Accessed: Nov. 22, 2018. doi: $10.1590 / \mathrm{S} 0100-40422007000500055$

BANCO MUNDIAL. Monitoramento e Avaliação: Algumas Ferramentas, Métodos e Abordagens. Washington-DC: Banco Mundial, 2004. Available from: <http://nweb90.worldbank. org/oed/oeddoclib.nsf/DocUNIDViewForJavaSearch/7BCBD7 07EDDD449885256F02006323BE/\$file/me_portuguese.pdf $>$. Accessed: Dec. 05, 2019. 